\title{
Failure cracks in reinforced concrete structures in Khartoum District
}

\author{
Prof. Dr. Salih Elhadi Mohamed Ahmed \\ Professor of structural engineering-Sudan University of Science \& technology \\ P.O. Box: 6417- Khartoum- Sudan
}

\begin{abstract}
Failure in reinforced concrete elements (Partial or complete collapse) may due to lack in design or in certainties of detailing or due to poor construction, or poor concreting and insufficient curing, or due to poor building materials, such as cement, aggregates and reinforcing steel.

Failure in reinforced concrete structures may also due to the movement of foundations or due to excessive vibrations in the neibour-hoods.

During the last 10 years (1998-2014) failure in reinforced concrete buildings in Khartoum district has been predominant.

The research contained in this paper is a result of a series of scientific case studies regarding failure or at least deficiency in some building complexes in Khartoum district carried by the author during his professional practice through his consultant firm named (Thiga for Engineering Consultants and Experimentation) located in Khartoum.

Many buildings (having number of stories range between 7-13 storey) has been studied according to scheduled investigations.

It has been found that the major reasons of these failure are duo to poor concreting, slab excessive deflection, excessive cracks in beams, foundation settlement, insufficient design, low thickness of slab, and other reasons.
\end{abstract}

\section{Introduction:}

Cracks may be caused by the external applied load on the structure just like flexural crack, shear crack, other cracks are also occurring independently, for example cracking of restrained members due to concrete shrinkage. Or temperature change, surface cracking of fresh concrete in plastic stage, and surface cracking of new concrete near reinforcing bar. However, the major cracks in concrete structures may be due to lack in design or details, bad instruction.

Settlement in foundation or due to the time factor (1). A typical study in Egypt showed percentage comparisons of these factors as shown in Fig. 1 (2).

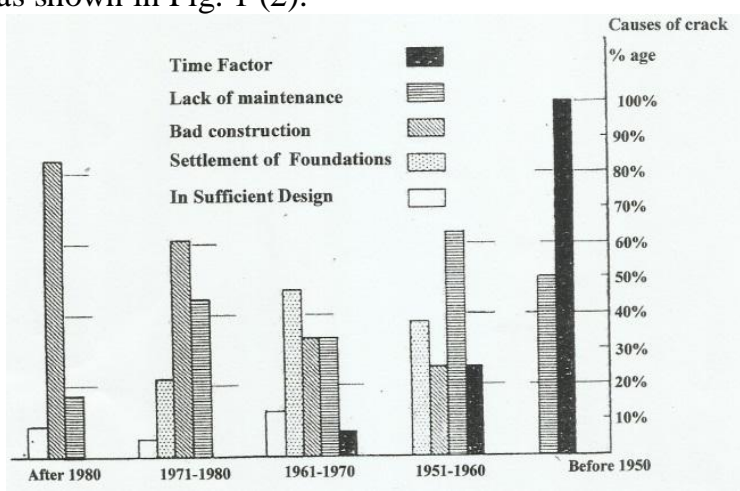

1.1 Other types of crack in buildings maybe summarized as:

Shrinkage cracks in buildings are unlikely to be of any structural concern but can be a source of water entry or radon entry in buildings and may form a tripping hazard.

- Settlement cracks in a slab indicate inadequate site preparation, such as failure to compact fill on which a foundation was poured.

- Frost heaves or expansive soil damage can cause substantial damage to basement, crawl space, or garage floor slabs in some conditions.

- $\quad$ Crack from settling of new addition. Anew addition has experienced settling as a result of soil consolidation at the new foundation.

- Crack formation due to soil related influences. Ground water can cause soil erosion and reduction of soil compressive strength, reduction load bearing capacity of the foundation, stressing and cracking building materials.

- Illustrate of structural member, which can occur for variety of reason such as defect or deterioration. This stresses on other building components, promoting crack formation. 
- Partial collapse of foundation, which is common among older stone foundation. Mortar has deteriorated and stones have fallen into the basement area. The loss of structural foundation support has caused cracking of drywall in the building interior. This is a form of deterioration.

- Cracks in wallboard due to settling.

- Cracks formed instantaneously as a result of a natural gas leakage fueled explosion in the building.

- Cracks in block wall about halfway up the wall. This is an indicator of soil and! or water pressure causing inward deflection of the wall and impending failure. In this case, water drainage toward the foundation had caused an excessive hydraulic load. Lock of maintenance of gutter drainage and grade near the wall has increased hydraulic loading against the wall over time. (see Fig. 2 for the differenftypes of cracks in buildings).

\subsection{Limits on crack width:}

It is necessary to identify limits of acceptability for crack widths. Max allowable in range of $0.1 \mathrm{~mm}$ to $0.4 \mathrm{~mm}$, one reason often given for limitation of crack width is prevention of corrosion of reinforcing steel. Table (1) present the permissible limits of crack widths (3).

Table (1): Permissible crack width:

\begin{tabular}{|l|l|}
\hline \multicolumn{1}{|c|}{ Member } & \multicolumn{1}{c|}{ Crack width (mm) } \\
\hline Dray air protection members & 0.4 \\
\hline Humility, moister, soil & 0.3 \\
\hline Deicing chemicals sea water and sea water spray & 0.15 \\
\hline Water retaining structures & 0.1 \\
\hline
\end{tabular}

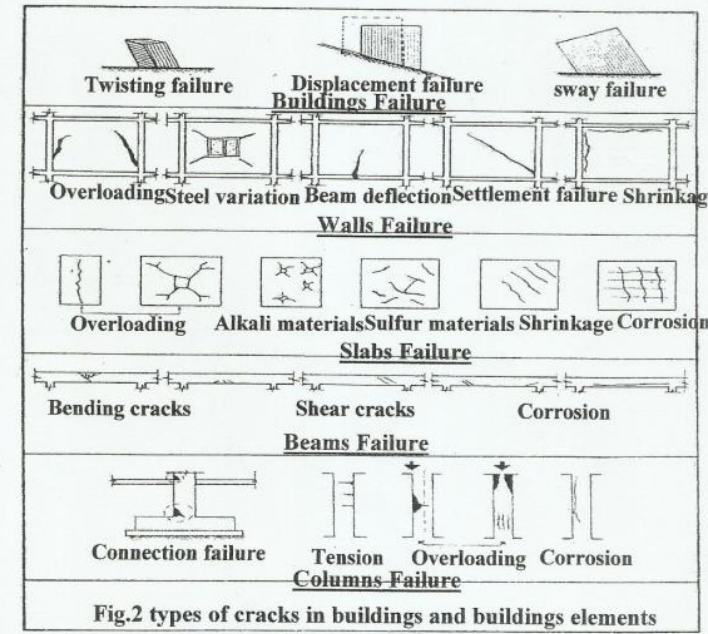

\section{Crack with calcuations}

\subsection{Standard Formula:}

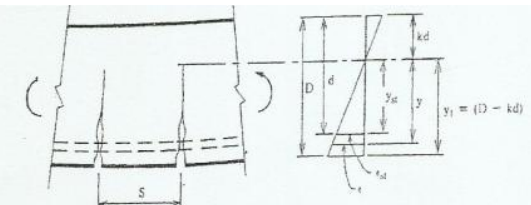

Fig. 3.a: Distribution of average strain in a beam

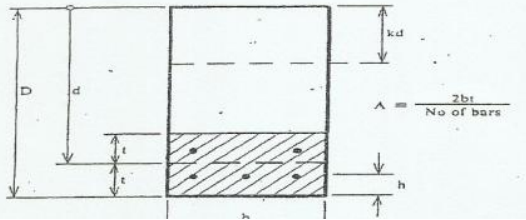

Fig. 3.b: Definition of A

Fig. 3. Crack width calculations

Taking fig.. (a \& b) under consideration, Welch and Janjua (4) proposed that the crack spacing $\mathrm{S}$ is given by:

$$
S=(1.5 h+3.0 d)
$$


Where $\mathrm{h}$ is the concrete cover measured to the bar centre and $\mathrm{db}$ is diameter; the same authors proposed the following formula for the maximum crack width;

$$
W_{\max }=1.5\left(1.5 h+3.0 d_{b}\right)\left(h+\frac{\sigma s t}{E s}+0.0001\right) \frac{y_{1}}{y_{s t}}
$$

The CEB- FIP model code (5) proposed the following formula for the crack spacing:

$$
S=2\left(h+\frac{\sigma}{10}+0.6 \frac{d_{b}}{p_{r}}\right)
$$

Where a is the spacing of the reinforcing bars and pr is the ratio of steel bar to effective surrounding area of concrete in tension.

Gergely and Lutz (6) has proposed that

$$
W_{\max }=0.011(h A)^{0.33}\left(\frac{D-k d}{d-k d}+0.0001\right) \sigma_{S I} \times 10^{-3} .
$$
each bar.

Where $\mathrm{h}$ is the minimum cover to the centre of the bar and $\mathrm{A}$ is the concrete tension area surrounding

ACI (7) proposed the following formula for the maximum crack width in fully cracked tensile members.

$$
W_{\max }=0.10 f s^{3} \sqrt{d_{c} A \times 10^{-3}} .
$$

Or

$$
W_{\max }=0.076 \beta f s^{3} \sqrt{d_{c} A \times 10^{-3}} .
$$

Where $\beta=$ ratio of distance between neutral axis and tension face to distance between neutral axis and centroid of reinforcing steel 1.2 in beams.

fs $=$ actual tensile strength of concrete in psi dc $=$ distance from centre of bar to extreme tension fiber in (in.)

$\mathrm{A}=$ area of concrete symmetric with reinforcing steel divided by the number of bars (in2).

\subsection{Effect of cracking on members stiffness:}

When a symmetrical un-cracked reinforced concrete member is loaded in tension the tensile force is distributed between the reinforcing steel and concrete in proportion to their respective stiffness. The load carried across the crack by reinforcement is gradually transferred by the bond to the concrete on each site of crack. As the applied load increases additional cracks form at distance intervals along the member and the stiffness is drop down, as a result of this drop, the member under cracking may finally fail. The contribution of concrete between cracks to the net stiffness of a member is known as tension stiffening.

\subsection{Finite element applications:}

Extensive researches has been done in recent years on the application of finite elements to modeling the behavior of reinforced concrete and is summarized in a report of the ASCE task committee on finite element analysis of reinforced concrete (8). Two basic approaches, the discrete crack approach and the smeared crack approach have been used to model cracking and tension stiffening.

\subsection{Deflection - calculation:}

Prediction of deflection is very important in order to avoid damage to finishes and services, although the estimation of exact deflection may be difficult due to some considerable effects on deflection calculation, such as:

- The long term creep effects.

- The effect of finishes, partitions ... etc.

- Shrinkage of the concrete.

- The precise duration of the live load. However, the max deflection (a) in concrete may be calculated using the following formula (9);

$$
a=K \frac{L^{2} M}{E_{0} I_{c e}} .
$$

where $\mathrm{K}$ is a coefficient that depends on the load distribution and the end fixity conditions.

$\mathrm{L}=$ length of the concrete member.

$\mathrm{M}=$ bending moment.

$\mathrm{E}_{\mathrm{c}}=$ modulus of elasticity of concrete

Ice $=$ second moment of area of the section in equivalent concrete units.

The permissible deflection in the building elements should not exceed the values given in table (2) 
Table (2) Permissible Deflection

\begin{tabular}{|l|l|}
\hline Member & Deflection \\
\hline Cantilever beam & Length/180 \\
\hline Beams carrying plaster & $\mathrm{Span} / 360$ \\
\hline All other beams & $\mathrm{Span} / 200$ \\
\hline Columns in multi-storey buildings & $\mathrm{Height} / 300$ \\
\hline Crane girders & $\mathrm{Span} / 600$ \\
\hline
\end{tabular}

Table (3): the studied buildings

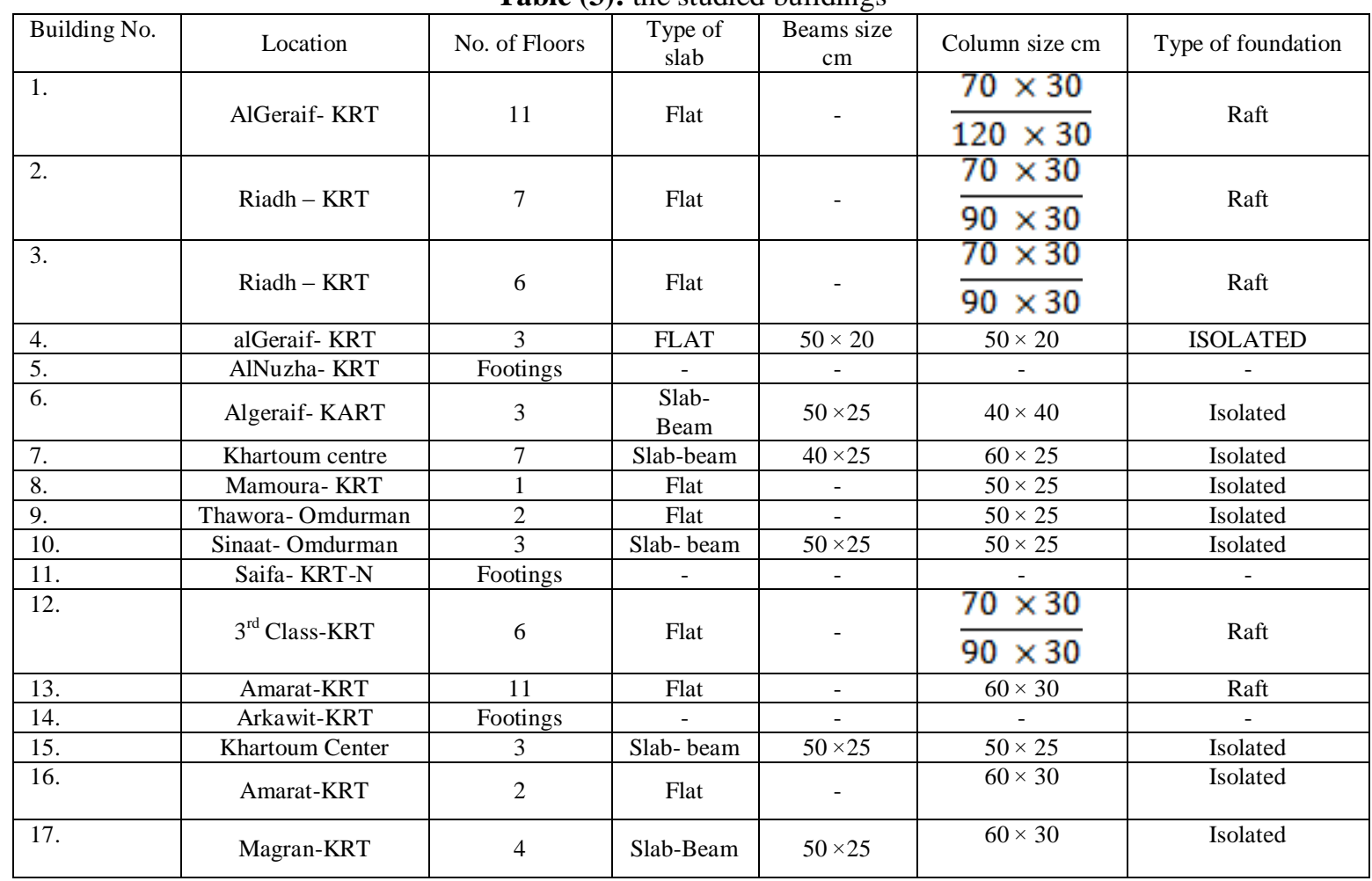

Table (4): Types of failures in the different buildings:

\begin{tabular}{|c|c|c|c|c|c|c|c|}
\hline Building & Types of failure & & & & & & \\
\hline & Concrete & Slab & Beam & Column & Foundation & Stability & Others \\
\hline 1. & - & $\begin{array}{l}\text { Excessive deflection in } \\
\text { one cantilever }\end{array}$ & - & - & - & - & - \\
\hline 2. & - & $\begin{array}{l}\text { Excessive deflection in } \\
\text { one cantilever }\end{array}$ & - & - & - & - & - \\
\hline 3. & - & $\begin{array}{l}\text { Excessive deflection in } \\
\text { one cantilever }\end{array}$ & - & - & - & - & - \\
\hline 4. & Poor concreting & & $\begin{array}{l}\text { Bending cracks } \\
\text { in beams }\end{array}$ & - & - & - & $\begin{array}{l}\text { Power work, } \\
\text { man-ship }\end{array}$ \\
\hline 5. & - & - & - & - & $\begin{array}{l}\text { Insufficient } \\
\text { foundations }\end{array}$ & - & $\begin{array}{l}\text { Power work, } \\
\text { man-ship }\end{array}$ \\
\hline 6. & - & & $\begin{array}{l}\text { Bending cracks } \\
\text { in beams }\end{array}$ & & $\begin{array}{l}\text { Insufficient } \\
\text { foundations }\end{array}$ & $\begin{array}{l}\text { Instability } \\
\text { condition }\end{array}$ & - \\
\hline 7. & Poor concreting & $\begin{array}{l}\text { Due deflection low to un } \\
\text { standard size of beam }\end{array}$ & $\begin{array}{l}\text { Major cracks in } \\
\text { columns }\end{array}$ & - & - & $\begin{array}{l}\text { Instability } \\
\text { condition }\end{array}$ & $\begin{array}{l}\text { Insufficient } \\
\text { design }\end{array}$ \\
\hline 8. & Poor concreting & Concrete segregation & Cracks in beams & - & $\begin{array}{l}\text { Settlement of } \\
\text { foundation }\end{array}$ & $\begin{array}{l}\text { Instability } \\
\text { condition }\end{array}$ & $\begin{array}{l}\text { Walls and } \\
\text { plasters cracks }\end{array}$ \\
\hline 9. & - & - & - & $\begin{array}{l}\text { In adequate slab- } \\
\text { column }\end{array}$ & - & - & - \\
\hline
\end{tabular}


Failure cracks in reinforced concrete structures in Khartoum District

\begin{tabular}{|c|c|c|c|c|c|c|c|}
\hline & & & & connection & & & \\
\hline 10. & Poor concreting & - & \multicolumn{2}{|c|}{ Cracks and deflection } & $\begin{array}{l}\text { Settlement of } \\
\text { foundation }\end{array}$ & $\begin{array}{l}\text { Instability } \\
\text { condition }\end{array}$ & $\begin{array}{l}\text { Walls and } \\
\text { plasters cracks }\end{array}$ \\
\hline 11. & Poor concreting & - & - & - & - & - & - \\
\hline 12. & - & $\begin{array}{l}\text { Excessive deflection in } \\
\text { columns }\end{array}$ & - & - & - & - & - \\
\hline 13. & Poor concreting & Concrete segregation & - & $\begin{array}{l}\text { Punching shear } \\
\text { in slab-column } \\
\text { connection }\end{array}$ & $\begin{array}{l}\text { Instability } \\
\text { condition }\end{array}$ & & $\begin{array}{l}\text { Insufficient } \\
\text { design }\end{array}$ \\
\hline 14. & Poor concreting & - & Cracks in G. Bs. & - & $\begin{array}{l}\text { Settlement in } \\
\text { foundation }\end{array}$ & - & - \\
\hline 15. & - & - & - & - & - & - & $\begin{array}{l}\text { Cracks in walls } \\
\text { and plaster }\end{array}$ \\
\hline 16. & - & Excessive deflection & - & Punching shear & - & - & Cracks in walls \\
\hline 17. & - & Excessive deflection & - & - & - & - & Cracks in walls \\
\hline
\end{tabular}

\section{Discussion of Results:}

The crack width calculations in the different buildings has ranged between $0.7 \mathrm{~mm}-15 \mathrm{~mm}$, all of it is more greater that the permissible crack width shown in table (1).

Regarding deflection in some members it has been recorded in two of the cantilevers of lengths $160 \mathrm{~cm}$ as $60 \mathrm{~mm}$ which is very excessive in comparison to table (2).

In reference to table (3) and table (4) that 17 reinforced concrete structures has been studied and the main type of failure has been presented and it has been found that the main types of failure is due to construction and lack in design and regarding the structural elements, the slabs and walls are suffering failure more than the other elements. Table (5) present the percentage comparison for the different causes of failure in the studied reinforced concrete elements in tables (3) and (4).

Table (5). Failure \% age comparison

\begin{tabular}{|c|c|c|c|c|c|c|c|c|c|c|c|}
\hline No. & $(1)$ & $(2)$ & $(3)$ & $(4)$ & $(5)$ & $(6)$ & $(7)$ & $(8)$ & $(9)$ & $(10)$ & $(11)$ \\
\hline $\begin{array}{c}\text { Type } \\
\text { of } \\
\text { failure }\end{array}$ & Poor & Poncreting & $\begin{array}{c}\text { Poor } \\
\text { excessive } \\
\text { deflection }\end{array}$ & $\begin{array}{c}\text { Low } \\
\text { thickness } \\
\text { of slab }\end{array}$ & $\begin{array}{c}\text { Excessive } \\
\text { cracks in } \\
\text { beams }\end{array}$ & $\begin{array}{c}\text { Punching } \\
\text { shear in } \\
\text { slabs }\end{array}$ & $\begin{array}{c}\text { Foundation } \\
\text { settlement }\end{array}$ & $\begin{array}{c}\text { Instability } \\
\text { condition }\end{array}$ & $\begin{array}{c}\text { Insufficient } \\
\text { design }\end{array}$ & $\begin{array}{c}\text { Cracks in } \\
\text { walls }\end{array}$ & $\begin{array}{c}\text { Inadequate } \\
\text { slab } \\
\text { column } \\
\text { Concrete } \\
\text { segregation }\end{array}$ \\
\hline$\%$ & $41 \%$ & $47 \%$ & $5.9 \%$ & $29.4 \%$ & $11.8 \%$ & $29.4 \%$ & $29.4 \%$ & $29.4 \%$ & $29.4 \%$ & $5.9 \%$ & $11.8 \%$ \\
\hline
\end{tabular}

\section{Conclusions:}

From the case study in this research, the following conclusions can be drawn:

1) The main cracks in reinforced concrete buildings are due mainly to lack in construction process.

2) Soil testing is very important before the design process of the reinforced concrete building.

3) The flat slab may be one of the main causes of failure in reinforced concrete structures due to the punching shear developed at the column face.

4) Insufficient design and poor detailing may lead to failure in reinforced concrete structures.

5) In design the ability requirements like the expansion joints, the reinforced concrete cores, and the shear walls should be taken under consideration.

\section{References:}

[1]. Future Engineering Group "Design of high rise building to resist wind and seismic loads" in Arabic, walid printing press, Egypt $1994,480 \mathrm{pp}$

[2]. Abu - Almagd. .et..al "Cracks in Reinforced Concrete Structures and its Repair", Egyptian Universities Printing Press, Cairo, 2007.

[3]. Concrete manual, 8th edition, U.S. Bureau of Reclamation, Denver, 1975, 627 pp.

[4]. Janjun, M.A and Welch, G.B "Magnitude and Distribution of concrete cracks in Reinforced concrete Flexural Members", UNICJV. Report No. R 78, Univ. of NSW, Kensington, 1972.

[5]. CEB-FIP Model Code for Concrete Structures, C\&CA, London, 1979

[6]. Gergely P., and Lutz, L.A "Maximum crack width in reinforced concrete flexural member", ACT publications, sp-20, Detroit, 87-1 17 pp. 1968.

[7]. 7. ACI $224-2 \mathrm{R}-92$, "Cracking of Concrete Members in Direct Tensiontt, re-approved 1997.

[8]. Finite Element Analysis of Reinforced Concrete, American Society of Civil Engineers, New York, 1982, 545 pp.

[9]. Morell, P. "Design of Reinforced Concrete Elements", Granda,U.K,1984. 